\section{Budget impact analysis of the percutaneous septal occluder for treatment of ostium secundum atrial septal defects in the Brazilian Unified National Health System}

\author{
Análise do impacto orçamentário do uso de \\ oclusor percutâneo septal para fechamento \\ de comunicação interatrial no Sistema \\ Único de Saúde
}

\author{
Análisis del impacto presupuestario en el uso del \\ oclusor percutáneo septal para la oclusión de \\ comunicación interauricular en el Sistema \\ Único de Salud brasileño
}

Kátia Marie Simões e Senna 1

Flavia Mori Sarti 2

Márcia Gisele Santos da Costa 1

Marcelo Eidi Nita 2

Marisa da Silva Santos 1

Bernardo Rangel Tura 1

Marcelo Goulart Correia 1

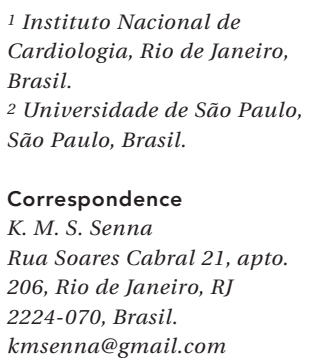

\begin{abstract}
The aim of this study was to perform a budget impact analysis on the adoption of percutaneous occlusion of ostium secundum atrial septal defects in the Brazilian Unified National Health System. Costs were collected using micro-costing technique from medical records for each treatment technique (conventional surgery versus percutaneous septal occluder) at a public federal hospital specialized in high-complexity cardiology. The analysis showed that expenditures associated with percutaneous occlusion were lower than with conventional surgery, and sensitivity analysis confirmed the cost reduction in several scenarios, showing a significant budget impact with a $30 \%$ adoption rate for the percutaneous occluder (savings of approximately 1.5 million dollars per year). The study indicates that the adoption of the percutaneous septal occluder would mean cost savings of approximately 3.5 million dollars for the Brazilian public health system.
\end{abstract}

Heart Septal Defects; Septal Occluder Device; Biomedical Technology; Thoracic Surgery; Health Evaluation

\section{Resumo}

O objetivo foi analisar o impacto orçamentário da incorporação do oclusor septal percutâneo para o tratamento de defeitos do septo atrial do tipo ostium secundum, sob a perspectiva do Sistema Único de Saúde brasileiro. Os custos foram coletados por microcusteio com base nos registros das intervenções terapêuticas (cirurgia convencional ou implante percutâneo de oclusor septal) realizadas em um hospital público federal especializado em cardiologia de alta complexidade. A análise identificou que os custos associados ao procedimento percutâneo de oclusor septal foram inferiores aos relacionados com a cirurgia convencional, a análise de sensibilidade confirmou a redução dos custos em diversos cenários e mostrou que o impacto no orçamento foi significativo a partir de uma taxa de incorporação de 30\% do oclusor septal percutâneo pelo sistema de saúde (redução dos gastos em torno de 1,5 milhão de dólares por ano). O estudo indica que a adoção do implante percutâneo do oclusor septal pode representar uma economia de aproximadamente 3,5 milhões de dólares para o sistema de saúde brasileiro.

Defeitos dos Septos Cardíacos; Dispositivo para Oclusão Septal; Tecnologia Biomédica; Cirurgia Torácica; Avaliação em Saúde 


\section{Introduction}

Atrial septal defect (ASD) is a congenital heart malformation characterized by a gap between the atrial cavities, representing $5 \%$ to $10 \%$ of congenital heart defects, predominantly in females. There are four different anatomical forms of atrial septal defects: ostium secundum (OS), ostium primum (OP), sinus venosus defect (SV), and coronary sinus defect (CS).The ostium secundum type has the highest prevalence, accounting for approximately $75 \%$ of ASD cases 1,2,3. Patients are usually asymptomatic during childhood, but some symptoms such as dyspnea, fatigue, palpitations, and syncope can occur 4.

The usual treatment for ASD-OS repair includes conventional surgery or percutaneous atrial septal occluder implantation. The decision to intervene in ASD is based on clinical and echocardiographic data, including signs and symptoms of right heart failure, size and location of the defect, magnitude and hemodynamic impacts of the left-to-right shunt, and presence and degree of pulmonary hypertension $6,7,8$.

Conventional surgery is based on classic median sternotomy under general anesthesia and cardiopulmonary bypass, which involves a postop period in a surgical intensive care unit and approximately seven days of hospitalization.

Occlusion using percutaneous septal occluder is performed with the patient under general anesthesia, supported by transesophageal echocardiography to establish the anatomic dimensions of the ASD and with the patient usually discharged within 48 hours post-procedure 8,9.

A literature review of the last decade shows that ASD occlusion using percutaneous septal occluder is a safe and effective alternative to conventional surgery and has been preferred for this treatment based on the superior results, including excellent aesthetic results, less trauma, the possibility of avoiding cardiopulmonary bypass, reduced length of stay, and low complication rates $(<10 \%) 4,10,11,12$.

International organizations have published guidelines in recent years indicating percutaneous occluder as the procedure of choice for treatment of congenital cardiopathy 4,13. However, in Brazil, conventional surgery is still the main treatment in hospitals under the Brazilian Unified National Health System (SUS).

A recently published economic assessment using Brazilian databases showed that ASD occlusion with percutaneous septal occluder is more cost-effective than conventional surgery 14 . The current study adds information to the results published by Costa et al. 14, aimed at providing evidence on the financial impact of adopting the percutaneous occluder, for decision-makers in the public sector of the Brazilian health care system, in order to support the definitive incorporation of percutaneous atrial septal occluder implant as the procedure of choice and its adoption in public hospitals.

The current study thus aimed to perform a budget impact analysis on introduction of the percutaneous septal occluder as the first option in health technology for the occlusion of ostium secundum ASD in the SUS.

\section{Methods}

The study estimated the financial impact of the incorporation of the percutaneous septal occluder compared to conventional surgery for ostium secundum ASD, in order to provide additional information to the economic assessment by Costa et al 14. Data on the efficacy and safety of the two procedures were obtained from a previously published systematic review 14 .

\section{Sample}

The budget impact analysis was performed using the database of a national reference hospital specialized in high-complexity cardiology in the Brazilian public sector using information from medical records collected for five years, including one year of follow-up on each patient, complemented with information from the Brazilian Ministry of Health and epidemiological data on the target population group.

The sample was based on data from the Brazilian Information System on Live Births (SINASC - http://www2.datasus.gov.br/DATASUS/index. php?area $=0205$, accessed on Oct/2011) of the Brazilian Ministry of Health, for 2010, the most recent year with available data 1 .

Epidemiological data on individuals with congenital cardiopathy were obtained from Brazilian studies published in the literature 1,2,3. Considering that nine out of 1,000 live born infants present congenital cardiopathies, $10 \%$ of which are ASD, and that $75 \%$ of the latter are the ostium secundum type, the number of individuals with ostium secundum ASD was estimated in order to calculate the sample size for each time period analyzed 15 .

To determine the sample for the analysis, we assumed that $75 \%$ of patients with ostium secundum ASD present the clinical and/or anatomical characteristics making them eligible for treatment using the percutaneous septal occluder ${ }^{1}$. 


\section{Costs}

The model considered the costs related to the two interventions (conventional surgery versus percutaneous septal occluder) for each patient from hospital admission until discharge.

Costs were analyzed from the perspective of the SUS, using data from a public federal hospital specialized in high-complexity cardiology, supplemented by information from the Brazilian Ministry of Health.

Direct medical costs of the two techniques (conventional surgery versus percutaneous septal occlude implant) were estimated with the micro-costing technique, using data from the public cardiology reference hospital, considering inputs for the procedures recorded on the hospital charts of patients diagnosed with ostium secundum ASD enrolled for treatment from 2006 to 2011, including one year follow-up. During the study period, 54 patients were treated with conventional surgery and 49 patients with percutaneous septal occluder in the hospital.

Variable costs (supplies and medication) were assessed using micro-costing techniques to identify the amount and type of each input used in the patients' treatment as recorded on medical charts and in hospital inventory systems. Each input's price was based on payment records for hospital materials obtained in 2012. Costs of complications were estimated according to differences between the procedure's average cost and the average cost obtained from medical charts from patients with complications.

Fixed costs related to the interventions were estimated using professional and hospital fees for procedures listed in the government reference tables (System for Management of Reference Prices: Table of Procedures, Medications, and Orthotics, Prosthetics, and Special Materials from the SUS - SIGTAP, version 1.2.0909141204. http:/ / sigtap.datasus.gov.br, accessed on Nov/2012) and calculated considering the number of procedures performed and the length of stay for each patient, considering the maximum amounts for transfer from SIGTAP and the number of tests performed during hospitalization. The amount of payment for percutaneous septal occluder under the SUS was estimated using the amount reimbursed for percutaneous occlusion of ductus arteriosus described in the SIGTAP, since the procedure is similar to the percutaneous septal occluder, which is still under evaluation for incorporation by the country's Unified Health System.

The analysis excluded the costs of post-procedure complications, due to the low incidence documented in the literature and to the relatively low costs associated with them, which thus pre- sented negligible impacts on the initially estimated results.

The amounts in Brazilian Reals (BRL) were converted to US dollars (USD) with November 2012 as the reference period, using the Brazilian Central Bank's official exchange rate.

Data analysis used the R statistical software package, version 3.0.1 (The R Foundation for Statistical Computing, Viena, Áustria; http:/ / www.rproject.org).

The project was submitted to the Brazil Platform (CAAE: 09842112.3.0000.5272) and assessed and approved unanimously by the Institutional Review Board of the National Institute of Cardiology, where data collection was performed. Opinion number: 155 223. Conclusion date: 27/ Nov/2012.

\section{Sensitivity analysis}

A sensitivity analysis was performed from simulations generated in the R software (The R Foundation for Statistical Computing, Viena, Áustria; http://www.r-project.org), based on estimation of distributions of probabilities for the model's variables, resulting from a range of probable situations that can cause price variations in the inputs, resulting in diverse costs for treatment of ostium secundum ASD with conventional surgery versus percutaneous occluder under different scenarios. Changes were simulated according adoption rates for the percutaneous septal occluder.

\section{Results}

Costs associated with the percutaneous septal occluder (U\$8,206.06) were lower than with conventional surgery (U\$10,701.80), excluding costs with complications (Table 1).

Annual budget impact was estimated, based on $25 \%$ of cases of ostium secundum ASD treated with conventional surgery and the remaining $75 \%$ with percutaneous septal occluder (Table 2).

Budget impact analysis indicated that approximately $17.5 \%$ of expenditures on treatment of $75 \%$ of patients diagnosed with ASD-OS would be attributable to incorporation of the percutaneous occluder by the Unified Health System, when compared to maintaining conventional surgery as the only treatment option. This represents a potential annual savings of more than 3.5 million dollars in health expenditures by the Brazilian public healthcare sector (Table 3).

Sensitivity analysis with Monte Carlo simulations confirmed the cost reduction under several scenarios, especially considering an increase in 
Costs related to conventional surgery versus percutaneous septal occluder for ostium secundum atrial septal defect (ASD-OS). Brazil, 2012.

\begin{tabular}{|c|c|c|c|}
\hline \multirow[t]{2}{*}{ Inputs } & \multicolumn{3}{|c|}{ Surgery } \\
\hline & Amount & Total cost (BRL) & Total cost (USD) \\
\hline Atrial septal occlusion (8 days) & & $11,912.27$ & $5,782.66$ \\
\hline Auto-transfusion set & 2 & 228.92 & 111.13 \\
\hline Peripherally inserted central catheter & 1 & 198.00 & 96.12 \\
\hline Double-lumen central venous catheter & 2 & 194.96 & 94.64 \\
\hline Centrifugal pump & 1 & 729.56 & 354.16 \\
\hline Echocardiogram & 8 & 319.52 & 155.11 \\
\hline Electrocardiogram & 8 & 41.20 & 20.00 \\
\hline Electrode for temporary epicardial pacemaker & 2 & 57.78 & 28.05 \\
\hline Extracorporeal circulation monitoring & & 60.00 & 29.13 \\
\hline Extracorporeal circulation set & 2 & $3,463.26$ & $1,681.19$ \\
\hline Complete blood count & 8 & 32.88 & 15.96 \\
\hline Medication and other medical supplies & & $4,551.15$ & $2,209.30$ \\
\hline Organic patch & 2 & 180.20 & 87.48 \\
\hline X-ray & 8 & 76.00 & 36.89 \\
\hline Overall cost of surgery & & $22,045.7$ & $10,701.80$ \\
\hline Overall cost of complications & & $10,38.28$ & 504.02 \\
\hline \multirow[t]{2}{*}{ Inputs } & \multicolumn{3}{|c|}{ Percutaneous septal occluder } \\
\hline & Amount & Total cost (BRL) & Total cost (USD) \\
\hline Transthoracic echocardiogram & 1 & 39.94 & 19.39 \\
\hline Transesophageal echocardiogram & 1 & 165.00 & 80.10 \\
\hline $\begin{array}{l}\text { Catheter (guide for percutaneous transluminal } \\
\text { angioplasty) }\end{array}$ & 2 & 390.90 & 189.76 \\
\hline Steerable guidewire for angioplasty & 2 & 390.90 & 189.76 \\
\hline Release set of interatrial prosthetics & 1 & $2,700.00$ & $1,310.68$ \\
\hline Prosthetics for ASD occlusion & 1 & $11,950.00$ & $5,800.97$ \\
\hline Ductus arteriosus percutaneous occlusion (1.5 days) & & 787.86 & 382.46 \\
\hline Medication and other medical supplies & & 479.89 & 232.96 \\
\hline Overall cost of percutaneous septal occluder & & $16,904.49$ & $8,206.06$ \\
\hline Overall cost of complications & & 421.02 & 204.38 \\
\hline
\end{tabular}

the adoption of the percutaneous septal occluder as standard treatment for ASD-OS. The estimated scenarios showed that the budget impact was significant with a $30 \%$ adoption rate of the percutaneous occluder in the health system (an annual spending cut of some 1.5 million dollars), but the most likely scenario $(60 \%$ adoption rate of percutaneous occluder) would represent an annual cost reduction of approximately 3.0 million dollars (Figure 1).

The sensitivity analysis indicated maintenance of the cost reduction, considering significant variations in the price of the percutaneous occluder device (with the most likely scenario suggesting an estimated annual spending cut of approximately 2.5 million dollars on ASD-OS treatment) and of conventional surgery (with the most likely scenario indicating an estimated annual spending cut on ASD-OS treatment of some 7.3 million dollars).

Summarizing the evidence from the budget impact analysis, considering variations in the cost of surgery versus percutaneous occluder with different adoption rates, the results remain positive for the adoption of percutaneous septal occluder (Figure 2), showing that the most likely scenarios range from zero to 19.0 million dollars annual reduction in health expenditures due to use of the percutaneous occluder for treating ASD-OS. 
Table 2

Estimated number of patients with ASD-OS and sample size calculation. Brazil, 2010-2015.

\begin{tabular}{llcccc}
\hline Period & Live births & $\begin{array}{c}\text { Congenital } \\
\text { cardiopathy }\end{array}$ & ASD & ASD-OS & $\begin{array}{c}\text { Percutaneous } \\
\text { occluder patients }\end{array}$ \\
\hline 2010 & $2,861,868$ & 25,757 & 2,576 & 1,932 & 1,449 \\
2011 & $2,846,731$ & 25,621 & 2,562 & 1,932 & 1,442 \\
2012 & $2,835,108$ & 25,516 & 2,552 & 1,914 & 1,436 \\
2013 & $2,826,183$ & 25,436 & 2,544 & 1,908 & 1,431 \\
2014 & $2,819,330$ & 25,374 & 2,537 & 1,903 & 1,427 \\
2015 & $2,814,067$ & 25,327 & 2,533 & 1,425 \\
\hline
\end{tabular}

ASD: atrial septal defect; ASD-OS: atrial septal defect ostium secundum.

Source: Information System on Live Births, 2010. http://www2.datasus.gov.br/DATASUS/index.php?area=0205,

accessed on Oct/2011).

Table 3

Budget impact analysis of surgery versus percutaneous septal occluder. Brazil, 2010-2015.

\begin{tabular}{lccc}
\hline Year & $\begin{array}{c}\text { 100\% patients with } \\
\text { conventional surgery }\end{array}$ & $\begin{array}{c}\text { 25\% patients with } \\
\text { conventional surgery } \\
\mathbf{7 5 \%} \text { patients with } \\
\text { percutaneous septal occluder }\end{array}$ & Difference \\
\hline 2010 & $20,675,870.10$ & $17,059,552.97$ & $-3,616,317.13$ \\
2011 & $20,568,852.14$ & $16,971,253.00$ & $-3,597,599.13$ \\
2012 & $20,483,237.77$ & $16,900,613.03$ & $-3,582,624.73$ \\
2013 & $20,419,026.99$ & $16,847,633.05$ & $-3,571,393.94$ \\
2015 & $20,365,518.01$ & $16,803,483.07$ & $-3,562,034.94$ \\
\end{tabular}

\section{Discussion}

The study discussed the budget impact associated with the cost of incorporating a new technology in the SUS for treatment of patients with ostium secundum atrial septal defect (ASD-OS). Percutaneous septal occluder has been deployed in the last three decades as an alternative method for treating ASD-OS and is considered safe and effective when compared to conventional surgery 16 .

Furthermore, percutaneous septal occlusion offers several benefits over conventional surgery, avoiding physical trauma and risks associated with extracorporeal circulation, blood transfusions, and increased length of hospital stay 17 .

Other advantages associated with intangible costs are probably underestimated, such as the reduction in psychological risks related to the surgical scar and trauma from hospitalization (particularly in the case of children) ${ }^{17}$. In other words, the main benefits of percutaneous occlusion are still difficult to measure, although they are particularly important to patients.

Percutaneous occlusion offers a lower probability of complications, since it is less invasive than surgery. Percutaneous septal occluder is also associated with reduced length of hospital stay ( 1.5 days $=$ U\$382.46) when compared to conventional surgery (8 days $=U \$ 5,782.66$ ). The price of the occluder device is more than offset within the procedure's overall cost due to the clinical and psychological advantages for the patient.

Kim \& Hijazi 18 showed a substantial cost reduction resulting from shorter length of stay and less time in the intensive care unit (ICU) when comparing percutaneous septal occluder to conventional surgery, corroborating our results.

One of the main barriers to incorporation of the percutaneous septal occluder is the high price 


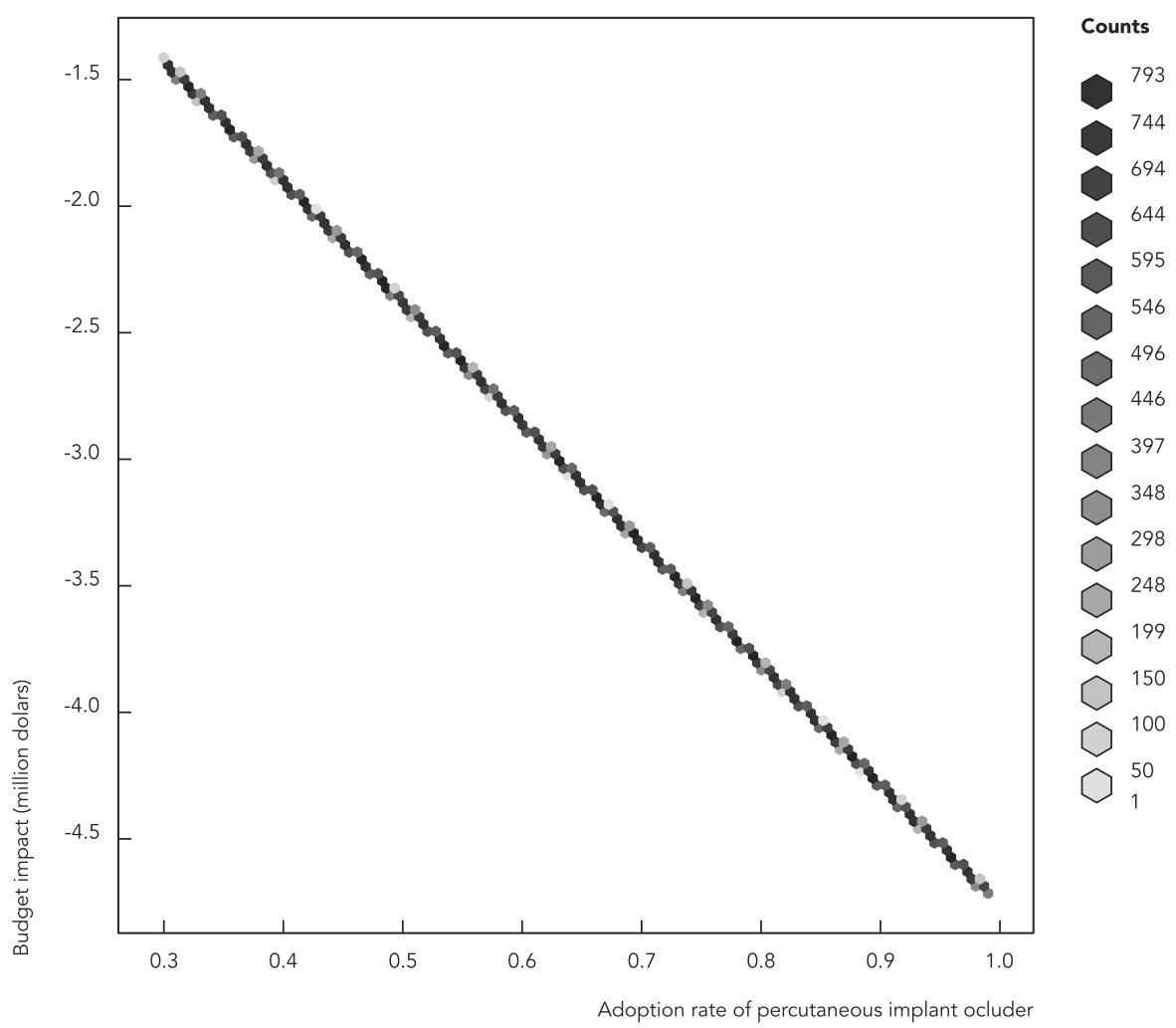

of the device in Brazil. Considering that adoption of the device by the Brazilian public healthcare system may increase the scale of its use and thus lower the cost, our budget impact analysis may actually have underestimated the potential gains from more widespread use of percutaneous occlusion for patients with ASD-OS in Brazil.

The incorporation of health technologies by the SUS is usually associated with high demand and increased costs, resulting in a significant adverse budget impact on the public sector. However, the percutaneous septal occluder showed a cost reduction, thus increasing the economic efficiency and improving access for patients with ASD-OS.

Percutaneous occlusion also requires less in terms of infrastructure and human resources when compared to conventional surgery (which requires an operating room and intensive care unit).

However, percutaneous occlusion must be performed by skilled and trained surgeons, that is, respecting the learning curve associated with the procedure's adoption and the need for tertiary healthcare services in order to minimize the risks associated with any medical intervention. Considering Brazil's geographic size and socioeconomic diversity, ASD-OS patients would probably receive better treatment in tertiary healthcare organizations that handle high-complexity procedures and are adequately prepared to perform percutaneous septal occlusion.

\section{Conclusion}

The current study indicates that adoption of the percutaneous septal occluder could result in savings of approximately 3.5 million dollars for the Brazilian public healthcare system. ASD-OS occlusion with the percutaneous septal occluder proved to be a safe and less invasive technique, with such advantages as shorter length of stay, reduced trauma, and fewer complications when 


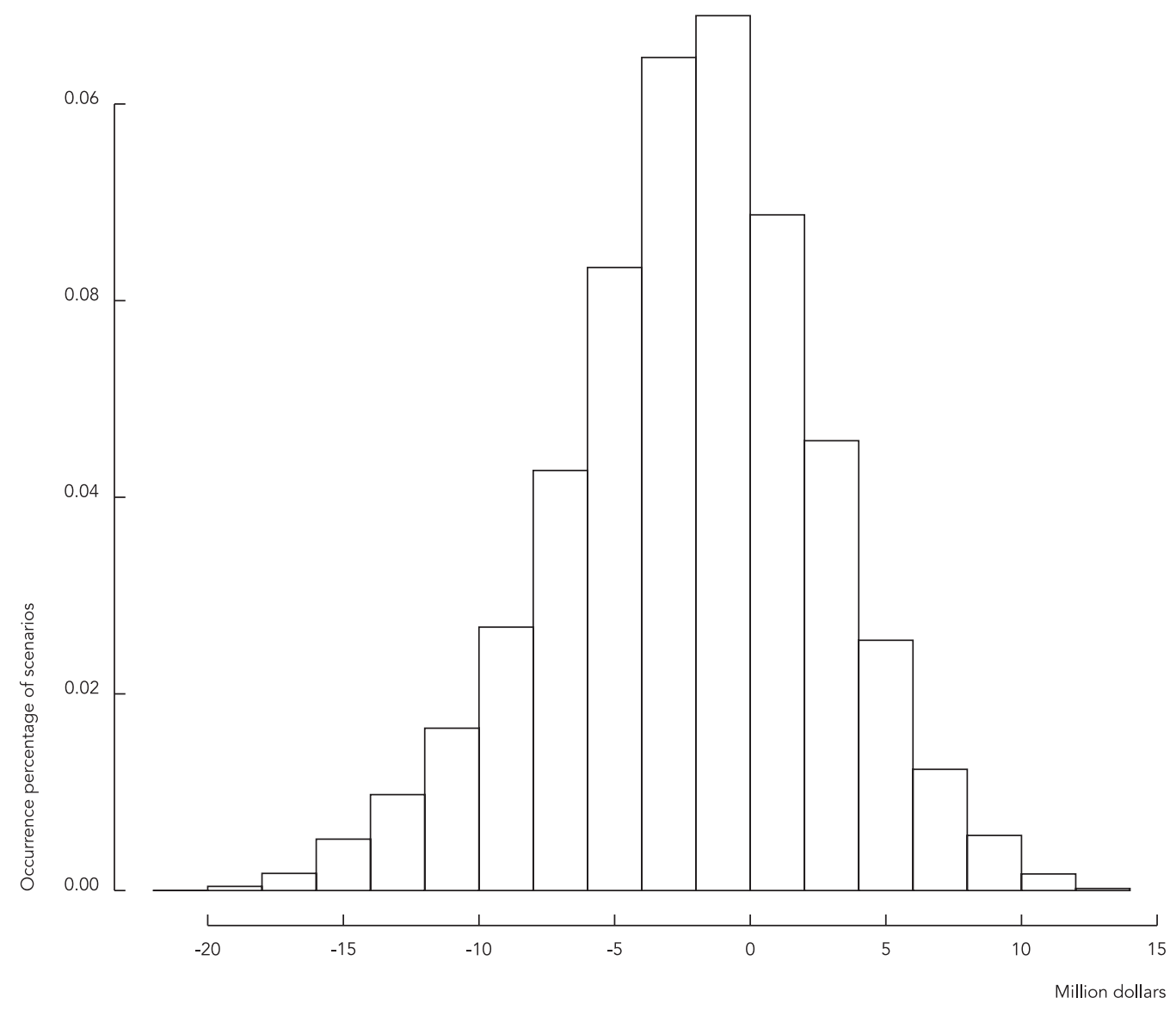

compared to surgery (the latter requiring blood transfusions, extracorporeal circulation, and immediate post-op follow-up in the intensive care unit).

The budget impact analysis was conducted as an addition to the economic assessment performed by Costa et al. 14, showing that the percutaneous septal occluder was significantly more effective and less costly when compared to conventional surgery from the perspective of SUS.

The aim of the authors was to provide input for public health sector decision-makers in order to support the definitive incorporation of percutaneous septal devices by the Brazilian healthcare system and its adoption by hospitals in the public sector. 


\section{Resumen}

El estudio consistió en analizar el impacto presupuestario de la implementación del oclusor septal percutáneo para el tratamiento de defectos del tabique auricular del ostium secundum, desde la perspectiva del Sistema Único de Salud. Los costes incluidos en el modelo por la técnica de micro-coste se obtuvieron de los registros de las intervenciones terapéuticas (cirurgía convencional u oclusor septal percutáneo) en un hospital público federal, especializado en cardiología de alta complejidad. El análisis reveló que los costos asociados con el oclusor septal percutáneo fueron más bajos que los asociados con la cirugía convencional, un análisis de sensibilidad confirmó la reducción de costos en diferentes escenarios y mostró que el impacto fue significativo desde una tasa del 30\% de incorporación del oclusor septal percutáneo por el sistema de salud (reducción en el gasto de alrededor de 1.5 millones de dolares por año). El estudio indica que la adopción del implante percutáneo del oclusor septal puede representar un ahorro de aproximadamente 3,5 millones de dólares anuales al sistema de salud brasileño.

Defectos de los Tabiques Cardíacos; Dispositivo Oclusor Septal; Tecnología Biomédica; Cirurgía Torácica;

Evaluación en Salud

\section{Contributors}

K. M. S. Senna was responsible for the study conception, data collection, analysis and interpretation of the results, writing of the initial version, and approval of the final version. F. M. Sarti was responsible for the analysis and interpretation of the results, writing of the draft in English, and approval of the final version. M. G. S. Costa was responsible for the study conception, data collection, analysis and interpretation of the results, and writing and approval of the final version. M. E. Nita was responsible for the analysis and interpretation of the results and writing and approval of the final version. M. S. Santos was responsible for the study conception, data analysis, interpretation of the results, and approval of the final version. B. R. Tura was responsible for the literature review, data analysis, interpretation of the results, and approval of the final version. M. G. Correia was responsible for the literature review, data analysis, and approval of the final version.

\section{Acknowledgments}

The authors wish to thank the Brazilian National Institute of Cardiology for its support in conducting the study.

\section{References}

1. Rossi RIF, Manica JLL, Cardoso CO. Oclusão percutânea de comunicação interatrial pelo Sistema Único de Saúde: uma opção economicamente viável. Rev Bras Cardiol Invasiva 2010; 18:212-22.

2. Pedra CAC, Pedra SRFF, Fontes VF. Comunicação interatrial do tipo ostium secundum: do tratamento cirúrgico ao percutâneo e os dinossauros do futuro. Arq Bras Cardiol 2003; 80:650-55.

3. Silveira AC, Rached EB, Campane FZ, Maielo JL. Comunicação interatrial. Rev Fac Ciênc Méd Sorocaba 2008; 10:7-11.
4. National Institute for Health and Clinical Excellence. Endovascular closure of atrial septal defect. London: National Health System; 2004.

5. Harper RW, Mottram PM, McGaw DJ. Closure of secundum atrial septal defects with the Amplatzer septal occluder device: techniques and problems. Catheter Cardiovasc Interv 2002; 57:508-24.

6. Sauer HH, Ntalakoura K, Haun C, Le TP, Hraska V. Early cardiac perforation after atrial septal defect closure with the Amplatzer septal occluder. Ann Thorac Surg 2006; 81:2312-3. 
7. Kamouh A, Osman MN, Rosenthal N, Blitz A. Erosion of an Amplatzer septal occluder device into the aortic root. Ann Thorac Surg 2011; 91:1608-10.

8. Vida VL, Barnoya J, O'Connell M, Leon-Wyss J, Larrazabal LA, Castañeda AR. Surgical versus percutaneous occlusion of ostium secundum atrial septal defects: results and cost-effective considerations in a low-income country. J Am Coll Cardiol 2006; 47:326-31.

9. Bové T, François K, De Groote K, Suys B, DeWolf D, Van Nooten G. Closure of atrial septal defects: Is there still a place for surgery? Acta Chir Belg 2005; 105:497-503.

10. Wei X, Yi W, Xu X, Zhang J, Li J, Yu S, et al. Transthoracic occlusion for secundum atrial septal defects unsuitable for transcatheter occlusion approach. J Thorac Cardiovasc Surg 2011; 142:113-9.

11. Brown SC, Bruwer AD, Harrisberg J, Govendrageloo K. Percutaneous closure of interatrial defects: the free state experience. Cardiovasc J S Afr $2004 ; 15: 28-31$.

12. Cardoso CO, Rossi Filho RI, Machado PR, François LM, Horowitz ES, Sarmento-Leite R. Effectiveness of the Amplatzer device for transcatheter closure of an ostium secundum atrial septal defect. Arq Bras Cardiol 2007; 88:384-9.

13. Feltes TF, Bacha E, Beekman RH 3rd, Cheatham JP, Feinstein JA, Gomes AS, et al. Indications for cardiac catheterization and intervention in pediatric cardiac disease: a scientific statement from the American Heart Association. Circulation 2011; 123:2607-52.
14. da Costa MG, Santos Mda S, Sarti FM, Simões e Senna KM, Tura BR, Goulart MC. Cost-effectiveness of procedures for treatment of ostium secundum atrial septal defects occlusion comparing conventional surgery and septal percutaneous implant. PLoS ONE 2014; 9:e108966.

15. Pinto Júnior VC, Daher CV, Sallum FS, Jatene MB, Croti UA. Situação das cirurgias cardíacas congênitas no Brasil. Rev Bras Cir Cardiovasc 2004; 19:III-VI.

16. Du ZD, Hijazi ZM, Kleinman CS, Silverman NH, Larntz K. Amplatzer investigators. Comparison between transcatheter and surgical closure of secundum atrial septal defect in children and adults: results of a multicenter nonrandomized trial. J Am Coll Cardiol 2002; 39:1836-44.

17. Hughes ML, Maskell G, Goh TH, Wilkinson JL. Prospective comparison of costs and short term health outcomes of surgical versus device closure of atrial septal defect in children. Heart. 2002; 88:67-70.

18. Kim JJ, Hijazi ZM. Clinical outcomes and costs of Amplatzer transcatheter closure as compared with surgical closure of ostium secundum atrial septal defects. Med Sci Monit 2002; 8:CR787-91.

Submitted on 12/Mar/2014

Final version resubmitted on 23/Dec/2014

Approved on 23/Feb/2015 